\title{
SOIL REINFORCEMENT AND EC7 (202x)
}

\author{
MaRTin VANÍČEK
}

\begin{abstract}
Geosyntetika Ltd., Nikoly Tesly 3, 16000 Prague, Czech Republic
correspondence: mvanicek@geosyntetika.cz
\end{abstract}

\begin{abstract}
Soil reinforcement is not really covered in current version of Eurocode 7 and therefore during the proposals for $2^{\text {nd }}$ generation of EC7 the soil reinforcement was highly promoted for inclusion in new EC7 based on the comments from practising engineers. In new EC7 which is now being written in newly created part 3 there will be next to other clauses also complete clause on Reinforced Ground. The paper will inform on the proposed contents of this clause.
\end{abstract}

KEYWORDS: Soil reinforcement, Eurocode 7.

\section{INTRODUCTION}

Existing Eurocode 7 covers soil reinforcement topic very vaguely. Together with ground improvement topic it is written just on half page [1, 2].

Once current Eurocode 7 was introduced to praxis, this state was highly criticised by geotechnical engineers around the whole Europe. This criticism was formally visible as outcome from periodic 5-year review.

As a result of whole Eurocode suite success, European Commission decided already in 2010 to update and further evolve the Eurocode suite towards its second generation.

\section{Development in BetWeEn 2010 AND 2015 IN SOIL REINFORCEMENT AREA}

Within the CEN technical committee TC250/SC7, which is responsible for Eurocode 7, fourteen Evolution groups (EG) were founded. Each EG concentrated on different specific subject of current EC7. EG 5 under the convenorship of the author focused on the introduction of the subject of reinforced soils into the Eurocode 7. Group members were from all around Europe.

Within this period comprehensive background document was developed, which covers most of typical applications of reinforced soil. We concentrated on specification of relevant limit states that should be checked during the design of such structures. Calculation methods for different limit states were discussed and compatibility of these methods was checked. The main differences were identified in the design approaches that were selected in specific countries.

Surprising recognition was combination of different design approaches used during checking of identified limit states even within one country. In some countries the former codes of praxis were combined with Eurocode 7, even when it meant combination of limit states approach with overall stability approach and hence very high (pointless) safety margins were required.

During this phase group was meeting face to face once a year within EC7 Workgroup meetings, which were held around Europe (e.g. in November 2014 in Prague). In the meantime, the group held online meetings in about 7 times a year, where further advancement and tasks for periods in between meetings were discussed.

It was agreed to focus in turn to the following types of reinforced soils:

- Reinforced embankment slopes

- Soil nailed slopes

- Walls from reinforced soil

- Subsoil reinforcement under embankments on soft soils

- Embankment on load transfer platforms over inclusions

- Embankments over possible voids

- Veneer stability

The structures that were agreed not to cover at the moments are reinforcement under shallow foundations and working platforms reinforcement.

Within ultimate limit states following locations of limit states origin were identified:

- In soil

- In reinforcing element

- On the interface between soil and reinforcing element

- At facing element

- The structure as a whole

It is possible to illustrate the identified limit states for given structure in the following Figure 1 .

For these limit states it will be necessary to define partial safety factors on both materials and resistances according to the design cases selected in particular country. 


\begin{tabular}{|c|c|c|c|c|c|}
\hline & $\begin{array}{l}\text { retaining } \\
\text { structures }\end{array}$ & $\begin{array}{l}\text { embankment } \\
\text { base }\end{array}$ & $\begin{array}{l}\text { piled } \\
\text { embankment }\end{array}$ & $\begin{array}{l}\text { voids } \\
\text { overbridging }\end{array}$ & $\begin{array}{l}\text { veneer } \\
\text { stability }\end{array}$ \\
\hline \multicolumn{6}{|l|}{ ULS } \\
\hline \multicolumn{6}{|l|}{ In soil } \\
\hline stability along slip surface (external, internal and compound) & $\mathbf{X}$ & $\mathbf{X}$ & $\mathbf{X}$ & & $\mathbf{X}$ \\
\hline Sliding & $\mathbf{X}$ & & $\mathbf{X}$ & & $\mathbf{X}$ \\
\hline Bearing capacity (including the excentricity) & $\mathbf{X}$ & & & & \\
\hline Squeezing & & $\mathbf{X}$ & $\mathbf{X}$ & & \\
\hline \multicolumn{6}{|l|}{ In reinforcement } \\
\hline \multicolumn{6}{|l|}{ Tensile rupture } \\
\hline Geosynthetic reinforcement & $\mathbf{X}$ & $\mathbf{X}$ & $\mathbf{X}$ & $\mathbf{X}$ & $\mathbf{X}$ \\
\hline Steel reinforcement & $\mathbf{X}$ & $\mathbf{X 1}$ & $\mathbf{X 1}$ & $\mathbf{X 1}$ & $\mathbf{X}$ \\
\hline Soil nails & $\mathbf{X}$ & & & & \\
\hline Anchors & $\mathbf{X 2}$ & & & & \\
\hline \multicolumn{6}{|l|}{ Shear rupture } \\
\hline Soil nails & $\mathbf{X}$ & & & & \\
\hline Rigid vertical bearing elements “RVBE” (Piles, micropiles, ...) & $\mathbf{X 2}$ & & $\mathbf{X 2}$ & & \\
\hline Tensile continuity (overlaps, connections, ...) & $\mathbf{X}$ & $\mathbf{X}$ & $\mathbf{X}$ & $\mathbf{X}$ & $\mathbf{X}$ \\
\hline \multicolumn{6}{|l|}{ On the interface between soil and reinforcement } \\
\hline Pull-out & $\mathbf{X}$ & $\mathbf{X}$ & $\mathbf{X}$ & $\mathbf{X}$ & $\mathbf{X}$ \\
\hline Stripping & $\mathbf{X}$ & $\mathbf{X}$ & $\mathbf{X}$ & & \\
\hline Sliding & $\mathbf{X}$ & $\mathbf{X}$ & $\mathbf{X}$ & & $\mathbf{X}$ \\
\hline \multicolumn{6}{|l|}{ Squeezing } \\
\hline Soil nails & $\mathbf{X}$ & & & & \\
\hline Rigid vertical bearing elements "RVBE” (Piles, micropiles, ...) & $\mathbf{X 2}$ & & $\mathbf{X 2}$ & & \\
\hline \multicolumn{6}{|l|}{ On facing elements } \\
\hline Connection to reinforcing element & $\mathbf{X}$ & & & & \\
\hline Bulging (blocks, steel mesh, wrap around, ...) & $\mathbf{X}$ & & & & \\
\hline \multicolumn{6}{|l|}{ SLS } \\
\hline \multicolumn{6}{|l|}{ In reinforced structure itself } \\
\hline Total vertical / horizontal deformation & $\mathbf{X}$ & $\mathbf{X}$ & $\mathbf{X}$ & $\mathbf{X}$ & $\mathbf{X}$ \\
\hline Relative vertical / horizontal deformation - post construction creep & $\mathbf{X}$ & $\mathbf{X}$ & $\mathbf{X}$ & $\mathbf{X}$ & $\mathbf{X}$ \\
\hline Relative deformation of the facing (bulging) & $\mathbf{X}$ & & & & \\
\hline \multicolumn{6}{|l|}{ In reinforcing element } \\
\hline Total strain (elongation) & $\mathbf{X}$ & $\mathbf{X}$ & $\mathbf{X}$ & $\mathbf{X}$ & $\mathbf{X}$ \\
\hline Creep strain (post construction) & $\mathbf{X}$ & $\mathbf{X}$ & $\mathbf{X}$ & $\mathbf{X}$ & $\mathbf{X}$ \\
\hline \multicolumn{6}{|l|}{ In facing element } \\
\hline Differential settlement along the facing due to subsoil deformation & $\mathbf{X}$ & & & & \\
\hline
\end{tabular}

FiguRE 1. Matrix of identified limit states and reinforced soil structures.

With respect to the need for definition of design strength of reinforcing element, there will be in the framework of second generation of Eurocode 7 defined a procedure for determination of strength for geosynthetic reinforcing elements, steel reinforcing elements and soil nails. The Evolution Group suggested following procedures to be incorporated into the EC7. An agreement between SC3 and SC7 was made that tensile strength of steel soil reinforcing elements will be covered in $2^{\text {nd }}$ generation of EC7 rather than in EC3 [3]. For steel reinforcing elements UK and French long-term experience and suggestions will be used. For geosynthetic elements the design strength will be adopted from ISO/TR 20432:2007 [4] that will be further extended to incorporate additional reduction factors from German specification EBGEO [5]. For soil nails design strength current Appendix to EN 14490 (Execution of soil nailed structures) will be adopted [6].

\section{Eurocode 7 DEVELOPMENT SINCE 2015}

The actual development of Eurocode $72^{\text {nd }}$ generation started in 2015 when Project Teams 1 and 2 were established. Team 1 was contracted to reorganize Eurocode 7 into 3 parts with common structure in all main clauses which will mimic the structure of other structural Eurocodes. Part 1 will be general and will be common to all geotechnical structures, part 2 will cover ground investigation and part 3 will cover all different geotechnical structures. Additional target for Team 1 was to propose simplifications to current text. All team 1 tasks are finished as of September 2017.

Task of Team 2 was to rewrite part 1 of Eurocode 7, so it includes the general subjects common to most of geotechnical structures and to prepare an alternative to existing Design approaches, which generate incompatibility in between individual countries with respect to design. At the same time the requirement was to make the Eurocode 7 fully compatible with Eurocodes 0 and 1, which specify the basis for limit states design and loadings on structures. At the end 
of October 2017 Team 2 prepared the final draft of EC7 part 1 for final comments by CEN National standards bodies. These comments have to be taken on board for the final part 1 deliverable at the end of April 2018.

Second and Third part of Eurocode 7 started to be updated in October 2017 as during the 2017 the Project teams 3, 4 and 5 were selected and appointed. Team 3 is responsible for updating of EC7 part 2 for Ground investigations. This part will be redrafted in that way that the main focus will be on determination of soil properties needed for geotechnical design from different investigation techniques, rather than the current situation when the focus is on tests. As part of Team 3 work will be specification of Ground investigation requirements and outputs including reporting.

Team 4 is responsible for only selected clauses of part 3, which cover the subjects of slopes, shallow and deep foundations and ground improvement. These clauses white spaces will be filled in, current text will be amended, refined and simplified to achieve the ease of use target. The clause on Ground improvement will be completely new.

Team 5, of which the author is member, is responsible for remaining clauses on geotechnical structures in EC7 part 2. More specifically these clauses are retaining structures, anchors and reinforced ground. The task of this team is also to fill in white spaces, amend, refine and simplify existing text, so it will be in accordance with basic structure of all Eurocodes.

This common structure of all Eurocodes should lead to simpler navigation through all Eurocodes parts.

The plan is that Teams 3 to 5 shall have ready in April 2019 first proper draft of their respective clauses. This draft will be than reviewed by TC250/SC7 committee and official comments submitted by them to Project teams. After that Project teams will prepare final draft by the end of October 2019. The October 2019 draft will be circulated to National standards bodies for official comments from CEN member states. These comments will lead to final text of respected parts by Project teams by the end of April 2020, when their tasks end.

There is also planned $3^{r d}$ phase of EC7 updating. This phase will be undertaken by Project Team 6, whose task is to amend the text of all 3 parts for rock mechanics and dynamic design. The schedule for Project Team 6 is 1 year behind Project teams 3,4 and 5, which means that they should conclude their work by April 2021.

Once all Project teams conclude their work the ownership of Eurocode 7 text will be transferred to TC250/SC7 committee, which will undergo the official process of acceptance voting by CEN processes. Sub- sequently the accepted text not only of Eurocode 7 but of all Eurocodes will be published by CEN, which is not expected before the end of 2022 .

The clause on Reinforced geotechnical structures will be based on output from Evolution group as described above. The main task will be to define the main limit states for different types of reinforced soil structures as indicated in Figure 1 and within informative annexes there will be suggested calculation methods for evaluation of selected limit states.

\section{Conclusions}

With respect to the situation that current version of Eurocode 7 practically does not cover the design of reinforced soil structures, it is a very positive signal to include these structures into the second generation of Eurocode 7. This inclusion means that these structures will finally be designed more or less the same way (by the same philosophy) all around Europe and even possibly around the world, where the system of Eurocodes is being used more and more. The design of reinforced soil structures will be more easily checkable even across borders.

For the Czech users of Eurocode 7 can be my presence in drafting of the new generation a good signal for keeping most design principles of existing design rules in the Czech Republic (valid since 1997) especially due to the fact that they are used for 20 years without any problems and are fully in accordance with existing Eurocode 7 and surely will be also with second generation.

\section{ACKNOWLEDGEMENTS}

Here I would like to thank to the Czech Geotechnical Society for the support in my presence on the preparation of second generation of Eurocode 7 .

\section{REFERENCES}

[1] ČSN EN 1997-1:2006. Eurocode 7: Design of Geotechnical Structures - Part 1: General Rules.

[2] ČSN P ENV 1997-1:1996. Design of Geotechnical Structures - Part 1: General Rules.

[3] ČSN EN 1993-5:2008. Eurocode 3: Design of steel structures - Part 5: Piling.

[4] PD ISO/TR 20432:2007. Guidelines for the determination of the long-term strength of geosynthetics for soil reinforcement.

[5] W. Ernst, S. Sohn. Deutsche Gesellschaft für Geotechnik e. V., DGGT (2011). Recommendations for Design and Analysis of Earth Structures using Geosynthetic Reinforcements - EBGEO. 340 p. Berlin.

[6] ČSN EN 14490:2010. Execution of special geotechnical works - Soil nailing. 